\title{
Radical Labour Law Reform and the Demise of the Victorian Industrial Relations System
}

\author{
Richard Mitchell and Richard Naughton*
}

\section{Introduction}

In October 1992 the newly elected Victorian state government (a coalition of the conservative Liberal-National Parties) under the leadership of Jeffrey Kennett introduced its legislative programme for deregulating the Victorian state industrial relations system. The most important in a series of enactments was the Employee Relations Act $1992^{1}$ (the ERA) which sought to implement a revolutionary new system of industrial relations inspired by the ideas of the "New Right" as they have emerged in Australia, and elsewhere, over the past twenty years (Mitchell, 1993a). These ideas, founded upon a supposed "economic rationalism", advocate the regulation of labour markets by voluntary agreement between employers and employees to the total, or at least substantial, exclusion of unions and state intervention.

The ERA repealed the Industrial Relations Act 1979, and abolished the former Industrial Relations Commission of Victoria, thereby dismantling the old compulsory arbitration framework. ${ }^{2}$ This was replaced by a new institutional structure in which the regulatory tribunal, the Employee Relations Commission (the ERC), was empowered to deal with an industrial matter or dispute and to exercise its powers only with the consent of all parties involved (ss.92(2) and 98(2), ERA). In place of the awards created under the old scheme, workplaces were principally to be regulated under a new regime based on individual and collective employment agreements directly negotiated between employers and employees.

* Centre for Employment and Labour Relations Law, The University of Melbourne.

1 Other aspects of the government's reform agenda were the Public Sector Management Act 1992 (which imposed the general framework established by the ERA on the Victorian public sector); the Annual Leave Payments Act 1992 (which abolished provisions in Victorian awards granting annual leave loadings); and the Accident Compensation (Workcover) Act 1992 (which restructured the system of workers' compensation existing in Victoria).

2 For much of its history the Victorian industrial relations system had operated on the basis of wages boards (more recently termed conciliation and arbitration boards). These boards (comprised of employer and employee representatives) were empowered to impose a settlement of an industrial dispute on the parties and were considered to be a variant of compulsory arbitration. The board system was replaced by a more conventional conciliation and arbitration system by the Industrial Relations (Enterprise Bargaining) Act 1992. For an analysis of the recent history of the Victorian system, see: Johnstone, McKenzie and Mitchell, 1993). 
The aims of the legislation as set out in the Minister's Second Reading Speech were, amongst others:

"to promote efficient and productive industry in Victoria, to develop a workplace
culture in which a new sense of co-operation and common effort exists between
employee and employer, to strengthen the rights of freedom of choice, of
freedom of association and to promote equality in the employer/employee
relations system" (Second Reading Speech, 1992).

Two years later it is possible to say that few, if any, of these objectives have been realised. In truth, for reasons we will explain, the Victorian industrial relations system has been effectively marginalised.

In many ways the success of the new system of "employee relations" in Victoria was predicated on the assumed certainty of a Liberal-National Party Coalition victory in the federal election poll, then due to be held in early 1993. It is unlikely that the architects of the ERA ever thought that Victoria could successfully go its own way in establishing a new system for regulating industrial relations. The system set in place by the ERA was strikingly similar to that encompassed in the industrial relations policy adopted by the federal coalition partners in the Jobsback document (Federal Coalition Parties, 1992). In the end result, of course, it was the Australian Labour Party which narrowly won the March 1993 federal election, partly it seems because of some concerns about the type of industrial system that had been set in place in Victoria.

In the meantime the federal government has successfully managed, through a number of legislative initiatives, to limit the impact of the Victorian reforms. Most importantly, changes to the Industrial Relations Act 1988 (Commonwealth) (the IR Act) have enabled large numbers of employees previously covered by Victorian state awards to escape into the federal system. As a consequence of these and other developments the "brave new world" of industrial relations trumpeted by the Kennett government has been rendered virtually irrelevant, and the ERC is required to play only a limited role in Victorian industrial affairs. Even the jurisdiction to deal with unfair dismissal claims, which was thought to be the chief area of work for the ERC, has been overtaken by recent federal reforms. ${ }^{3}$

The large number of Victorian workers who have managed to shift into the federal system is simply the most obvious manifestation of the failure of the new industrial system promoted by the Kennett government. A number of reasons have been given to explain why the ERA has not achieved its objectives. These include the way in which the legislation was originally conceived, and also its overriding philosophy and content. For example, the government was trenchantly criticised for the lack of consultation which preceded the introduction of the ERA and the haste with which it passed through parliament (Creighton, 1993: 158). There was little opportunity for public debate on the legislation as it was forced through both houses of parliament in less than two weeks. Another frequently expressed criticism concerns the poor drafting of aspects of the

3 The unfair dismissal provisions were introduced into the IR Act by the Industrial Relations Reform Act 1993 (C'th). They apply to all Australian employees. 
legislation (Mitchell, 1993; Creighton, 1993) and some muddled thinking over conceptual issues.

The government's determination to implement its industrial reforms in such a fashion has exacted a significant cost. There was considerable public opposition to the industrial changes expressed in the form of well attended protest rallies. Associated with this has been the attitude of Victorian unions (led by the Trades Hall Council) which have simply refused to accept the legitimacy of the Kennett government's industrial reforms. The conjunction of these factors seems to have undermined whatever chance of success the radical reforms may have had.

\section{An outline of the ERA}

In general terms, the thrust of the ERA is to replace the former Victorian industrial system (that was focussed upon collective labour relations issues) with a system primarily aimed at individual agreements. This primacy of industrial relations between individual parties and the removal of the role of state regulation is borne out in the various objects of the Act. One of the ERA's purposes is to establish a system "which facilitates the freedom of employers and employees to choose how they regulate their own affairs" (s.3(b), ERA).

The support for voluntary agreements between employers and employees has its source in the belief that the market operates as the most effective and fair means of distributing and allocating resources (Brook, 1990). Freed from outside regulation, enterprises can adjust more readily to the needs of their product or service markets. Voluntary agreements are thus allied to economic performance - the parties can freely adjust their relations in accordance with the needs of the enterprise. The economic rationale for the new system is emphasised in the first-mentioned object of the ERA which is to "promote efficient and productive industry in Victoria and an efficient labour market" (s.3(a), ERA). The alternative view, of course, is that the system effectively ensures that the interests of employees are made subservient to the commercial interests of the employer and the enterprise. It has been suggested, for example, that the system would be more appropriately titled an "employer relations" rather than an "employee relations" system (Mitchell, 1993: 25).

The provisions of the ERA allow for collective employment agreements (agreements made between an employer and two or more employees) and individual employment agreements. The legislation clearly favours individual agreements over collective agreements, and indicates that the individual agreement will prevail in the event of any inconsistency between them. Both collective and individual agreements are required to be in writing and must include the minimum terms and conditions of employment which 
appear in Schedule 1 of the ERA. ${ }^{4}$ However, it is only collective employment agreements which must be filed with the Chief Commission Administration Officer (the CCAO) of the ERC. There is no requirement to file individual employment agreements with the ERC, although s.13(2) requires that employers notify the CCAO of the number of individual agreements by which they are bound on an annual basis.

There are some odd features of these requirements. According to s.13(3) of the ERA the information contained in collective agreements filed with the CCAO is only to be made available to the parties to the agreement or some person authorised to enforce the agreement on their behalf. On the face of it the provision appears to deny the CCAO (and also inspectors appointed to enforce the legislation) direct access to the agreements, and prevents that officer from routinely scrutinising those agreements to determine whether they comply with the various statutory minima specified in the ERA (Mitchell, 1993).

The role of unions in the bargaining process is minimal, at best. The only role envisaged by the ERA is for the union to act as a bargaining representative for an individual employee or group of employees when so authorised by those employees (ss.8(3)(b) and $9(3)(\mathrm{b})$, ERA). Even where this is the case, however, there is no obligation on the employer to bargain with the union. The ERA indicates merely that the employer "may" negotiate towards an agreement.

One interpretation of the legislative philosophy of the ERA is that it sets out to obstruct the role of unions at each and every step in the industrial relations process. Thus, it is possible for a union to seek "recognition" under the legislation for various purposes, but it is no longer automatically entitled to represent the interests of workers who fall within its rules. It is also impermissible to include a trade union security device (a preference clause or a closed shop arrangement) in an employment agreement or an award of the ERC (ss.54 and 55, ERA). One of the express objects of the ERA is the protection of freedom of association (s.3(a)), but the government's ideological focus is quite obviously upon an individual's right to work in an environment free of union membership.

Another notable feature of the ERA is to establish offences for participation in what is termed "unlawful industrial action" (s.36(2), ERA). ${ }^{5}$ Theoretically, at least, the legislation appears to permit "lawful" industrial action where this takes place during the negotiation phase of a collective agreement. However, the procedural steps which must be followed (including authorisation of the action by secret ballot) and the wide range of circumstances which render industrial action unlawful (s.36(1)(a)-(h)) make this supposed right to strike more illusory than real (Pittard, 1993). The heavy penalties that might be imposed in the event of unlawful strike action confirm the general anti-union

4 Schedule 1 refers to minimum wage rates, and minimum standards with respect to annual leave, sick leave, and parental leave. Amendments to the legislation (which have recently been announced) will add certain minimum entitlements in the event of termination of employment (notice periods and severance pay). See Employee Relations (Amendment) Bill 1994.

5 As yet no prosecutions have been instituted under this provision. 


\section{flavour of the ERA.}

A breach of an employment agreement can give rise to both civil and criminal proceedings before the Industrial Division of the Magistrates' Court (ss.19 and 163, ERA). For example, it is an offence for an individual to fail to comply with any provision of an agreement which "imposes an obligation on the individual." ${ }^{6}$ At the time the legislation was introduced there was considerable criticism about these provisions, as they appeared to reintroduce the criminal sanctions reminiscent of antiquated master and servant legislation. On the face of it, it must be said that the imposition of penal sanctions to be used to enforce what is essentially a private contractual arrangement appears strange.

The prospect of civil or criminal liability for breach of an agreement reinforces the argument that the ERC (through the CCAO or inspectors) should have the ability to scrutinise the terms and conditions of employment agreements. Notwithstanding the wide ambit of liability imposed by the ERA on employers and (more obviously, presumably) on employees, there is no opportunity given to challenge the validity of an agreement on the ground that the process of its formation was unfair or that it is harsh and unreasonable in its terms or operation (Mitchell, 1993: 11). This kind of criticism has now been made by the ERC itself, which has called for the introduction of a mechanism to allow for the independent scrutiny of individual and collective employment agreements (Employee Relations Commission, 1994). What appears to be sought is some power whereby the ERC is authorised to intervene and vary agreements when it is demonstrated that they breach minimum requirements or are otherwise unfair.

The reliance on employment agreements as the central plank of the Victorian industrial system emphasises the priority given to private contractual arrangements between employers and employees over industrial awards. All the existing awards of the former Industrial Relations Commission of Victoria were abolished as from 1 March 1993. Since that time, it has only been possible for parties to opt-back into the award stream by agreement, and in fact no fresh awards have been made by the ERC. ${ }^{7}$ It is, nevertheless, interesting that the expired awards of the former Commission have (at least to date) continued to be of importance. For example, any award-governed employee who fails to enter an employment agreement is regarded as having an implied employment agreement based upon the terms and conditions of the expired award. In addition, the minimum wage rate provision in Schedule 1 (at least until some legislative amendment in December 1993) was based upon the relevant rate in the expired award, and it has (at least until recently) been necessary for applicants in unfair dismissal proceedings to be

6 See s.163, ERA. At the time of writing no prosecutions have been initiated under this provision.

7 It now appears that the ERC's award making jurisdiction will be removed as a result of changes announced in the Employee Relations (Amendment) Bill 1994. However, the ERC retains the power to arbitrate with the consent of all parties to the dispute. It is unclear how the ERC is to make binding the result of its arbitration in the absence of a power to make awards. It has no explicit power to make orders or give directions. Some power might be implied from s.100(1)(c) (which enables the ERC to "do anything that is necessary or expedient to enable it to perform its functions"), but it appears that the abolition of all power to make awards is an oversight. 
performing work that fell within a classification covered by the award as at 1 March 1993.

It is fair to say that the legislation was full of rather astonishing pitfalls. One of the apparent problems that was soon identified was that there was no mechanism to update or review the statutory minima in Schedule 1. This meant that the minimum wage rates in the Schedule were "frozen" as the rates which appeared in awards that expired on 1 March 1993. It also seemed that the statutory minima only applied to the written employment agreements contemplated by the ERA, but not necessarily to arrangements which did not satisfy this statutory description. In essence this meant that the minimum requirements in Schedule 1 did not apply to ordinary contracts of employment, or it seems, to employment agreements made by workers who were not formerly covered by a state award (Creighton, 1993: 153).

The limitations on the award-making power of the ERC reflect the operational constraints imposed on the new tribunal authorised to regulate employee relations in Victoria. As a general proposition the ERC must not convene any proceedings or exercise any of its powers without the consent of all parties (ss.92(2) and 98(2), ERA). The ERA sought (at least initially) to remove the powers of compulsory arbitration from the state industrial tribunal, and replace it with something in the nature of a "voluntarist" system (Naughton, 1993). Gone from the ERA was the idea that the state is a natural player in industrial relations contests - the parties were left to take care of themselves.

The one specific exception (in the original legislation) to the proposition that the ERC lacked compulsory arbitration powers arose in the case of unfair dismissal claims. However, even though employees do have a statutory right to challenge the fairness of a dismissal, it has been made subject to a series of jurisdictional and technical restrictions. $^{8}$ This means that the rights of dismissed employees are considerably less than existed under the former Industrial Relations Act 1979, and in other state jurisdictions. If an applicant successfully manouevres his or her way through the minefield of legislative restrictions, the only possible remedy is that of reinstatement, and damages for lost wages from the dismissal until the date of hearing. The ERC has no general power to award compensation to an unfairly dismissed employee.

\section{The Federal response to the new Victorian regime}

As noted earlier, the muted impact of the Victorian reforms has been due to at least two major factors. First, the Victorian Trades Hall Council led an aggressive campaign against the legislation, including well attended public protests, and has since continued

The more important of these are that the employee: (a) has been engaged in a classification of work that was covered by an award as at 1 March 1993; (b) has been employed continuously for a six month period; and (c) has no rights of appeal or review in respect of the dismissal under any contract or other legislation. It is also necessary for an applicant to demonstrate the existence of a prima facie case in proceedings before the CCAO. It appears that the limitations in (a) and (b) will be removed as a result of legislation currently before the Victorian parliament. See Employee Relations (Amendment) Bill 1994. 
to run a successful industrial boycott of the legislation. However, the major factor in bringing down the credibility of the Victorian system has been the strategic response of the federal government. In the period since December 1992 there have been two major initiatives which were directed against the industrial system contemplated by the ERA. The first of these was to make it easier for employees traditionally regulated by state awards to move into the federal system. The second was to establish a mechanism whereby it became possible for employees hitherto covered by state awards to apply to the federal tribunal for an order setting minimum wages.

Traditionally there has been a number of restraints upon state award employees moving into the federal system. For example, until December 1992 it was possible for the federal tribunal to either dismiss a matter or refrain from further hearing of it, where the issue was more properly dealt with by "a state industrial authority", or where proceedings were not desirable in the public interest. In December 1992 these provisions were amended to limit the circumstances where the federal tribunal could be prevented from hearing a matter and ultimately making an award. For example, the words, "a state industrial authority" were replaced by the expression "a state arbitrator" (which meant a state industrial authority with compulsory arbitration powers) (s.111(1)(g)(ii), IR Act). Further, the power to refrain from hearing a matter in the public interest was stated not to apply in circumstances where the terms and conditions of employment of employees could not be set by "a state arbitrator by compulsory arbitration" (s.111(1A)(b), IR Act). The evident purpose of these amendments was to make it easier for employees within the Victorian system, or any other similar system introduced by a state government, to seek federal award coverage. The amendments were cast in general terms which made it possible to argue that they were not specifically directed at Victoria, but the reasoning behind the changes is obvious enough. As a result of the changes introduced by the ERA, Victoria is the only state system where the regulatory tribunal lacks powers of compulsory arbitration.

The second change at federal level which appears to be specifically directed at Victoria concerns the minimum wage rate provisions which now appear in the IR Act. These were part of a regime of minimum employment standards introduced into the federal legislation by the Industrial Relations Reform Act 1993 (C'th), and which are based upon a series of ILO Conventions. ${ }^{9} \quad$ These minimum employment standards are stated to apply to all Australian employees, although the minimum wage provisions can only be utilised in circumstances where minimum wages are unable to be fixed or adjusted by a state arbitrator (s.170AE(3)(a), IR Act). This provision provides Victorian employees with a general right to apply to the federal Commission for an order fixing a minimum wage for all employees in a particular group or category. Another important aspect of the Industrial Relations Reform Act 1993 (C'th), in its impact on the Victorian industrial system, is the provision for unfair dismissal rights granted to all Australian employees (ss.170EA-EH, IR Act). It is evident that the availability of compensation as a remedy in the federal system (s.170EE, IR Act) will encourage Victorian employees to pursue

9 The minimum standards are minimum wage rates, equal remuneration for work of equal value, specific rights upon termination of employment (including unfair dismissal rights), and parental leave. 
their application under the IR Act. The absence of compensation as a remedy under the ERA means that its provisions are unlikely to be considered an "adequate alternative remedy" as required under s.170EB of the IR Act. This provision indicates that the federal Industrial Relations Court must not hear a dismissal claim if the relevant state jurisdiction offers an adequate alternative remedy (which appears to mean that it allows for the remedies of either reinstatement or compensation to the unfairly dismissed employee). This mechanism will no doubt operate to further limit the work of the ERC.

As suggested earlier, one of the perceived flaws with the industrial system established by the ERA was the lack of an express mechanism to adjust the minimum wage rates applying to agreements specified in Schedule 1. These minimum wage rates are "frozen" as the rates applicable in awards which expired on 1 March 1993. This limitation became especially apparent after the federal tribunal's Review of Wage Fixing Principles in October 1993. The tribunal's decision recommended an $\$ 8.00$ pay increase for lowerpaid workers, but there was no mechanism whereby this could be passed on to Victorian employees. Ultimately, the Victorian Government decided to amend the ERA to correct this problem. In December 1993 it introduced a new section 113A which allowed the ERC to review the provisions of expired awards upon reference by the Minister. As part of this review process the ERC was empowered to amend or vary the award and thereby, through this circuitous process, increase existing minimum wage rates. It was immediately apparent that the new provision appeared to introduce a limited form of compulsory arbitration into the Victorian system, although it did not seem likely that this would compromise the overall voluntarist strategy envisaged by the ERA.

The process for reviewing awards implemented by s.113A enabled the ERC commence a full-scale review of the expired awards of the former state Commission i early 1994. For the most part the review was limited to adjusting wage rates in awards to allow for a flow-on of the $\$ 8.00$ National Wage increase, but in a number decisions the ERC suggested that its powers to alter and vary awards were not so limited. The most contentious decision arose in a case involving various regulations and determinations affecting public sector employment (the SPSF decision). Ultimately the ERC inserted regulations dealing with enterprise bargaining into various public service awards which had expired on 1 March 1993. The new provisions purported to establish a framework for the conduct of enterprise bargaining within the Victorian public sector. The importance of the SPSF decision was the ERC's assertion that s.113A was not subject to ss.92(2) and 98(2) of the ERA (i.e. those provisions which require the consent of all parties before the ERC can exercise arbitral powers). In addition, the Tribunal indicated that its power to unilaterally vary awards was not limited to adjusting minimum wage levels. The ERC thereby assumed powers of compulsory arbitration and issued an important policy challenge to the government.

\section{The Victorian counter-response}

By the middle of 1994 it was evident that the government's industrial philosophy was under seige on a number of different fronts, most particularly the ERC's assumption of arbitral powers, and the federal legislation allowing state employees to move into the 
federal system, and for minimum wage orders to be made covering Victorian employees. In October 1994 the Victorian government sought to resolve these problems by introducing the Employee Relations (Amendment) Bill 1994 (the amendment bill). The amendment bill purports to achieve a number of important objectives: it entirely removes the ERC's award-making jurisdiction; it expressly grants the tribunal arbitral powers in a number of narrowly circumscribed areas; and it enables the ERC to fix minimum wages for employees working in a number of designated industrial sectors. ${ }^{10}$

Granting the ERC arbitration powers is obviously a mechanism designed to overcome some of the difficulties caused by the federal legislation aimed at state systems which lack such power. In future the ERC will be empowered to make minimum wage orders for various industrial sectors, and for groups and classifications of employees within those sectors. It would, nevertheless, appear that the ERC's powers depend upon the Minister first referring a dispute or matter to the tribunal. All the arbitral powers concerning minimum wages granted by the amending bill depend upon there being a preliminary reference by the Minister. One question which is certain to arise is whether these restrictions and limitations upon the ERC's powers will actually prevent it from being "a state arbitrator" in the terms of the IR Act. If so, the federal tribunal will continue to have the power to make minimum wage orders in relation to Victorian employees, and the escape route into the federal system will remain available.

The amending bill also includes a new s.99 of the ERA which sets definite limits upon the ERC's arbitral powers. It appears that the ERC may only arbitrate in four particular circumstances: where the parties consent to this course of action; in the event of unfair dismissal proceedings; in circumstances of a particular reference by the Minister under $\mathrm{s.113}$; and in an application to set or adjust a minimum wage. The provision appears to be specifically directed to the ERC's apparent challenge to the government in the SPSF decision. Clause 12(1) of the amending bill purports to quash that decision, while clause 12(4) enacts that the ERC is deemed only to have power to vary expired awards to provide for the flow-on of safety net adjustments made by the Federal Tribunal in its Review of Wage Fixing Principles. In particular, the amending bill expressly states that the ERC is "deemed not to have, and to never have had" power to add particular provisions concerning enterprise bargaining (which included a last-resort arbitration power invested in the ERC) into various public sector awards.

\section{The end of an industrial relations system?}

It is perhaps too early to proclaim the Victorian industrial relations system dead. It is, however, obviously seriously ill. It remains to be seen what impact the recent

10 The amending bill also clarifies a number of the minimum employment standards in Schedule 1 , and adds additional statutory minima concerning notice and severance pay in the event of termination of employment. The unfair dismissal provisions will be altered to take account of the abandonment of the ERC's award jurisdiction. Other changes include the imposition of a $\$ 60,000$ salary ceiling upon the applicants for unfair dismissal, and the removal of the mandatory requirement that applicants have been employed for six months. 
amendments to the ERA will have, but it is unlikely that they will be other than marginal.

Although an accurate assessment is impossible to obtain, the numbers of employees who have shifted from the Victorian jurisdiction to the federal jurisdiction is substantial. Recent research (Fox and Teicher, 1994) indicates that at least 200,000 workers have successfully made the shift, with an upper figure of 345,000 being a maximum estimate. The state government itself conceded that at least 150,000 workers had left the system by the end of 1993 (Fox and Teicher, 1994). By any estimate these are substantial figures. In May 1990 the ABS figures revealed that the workforce covered by the awards of the Victorian system was something in the order of 637,000 employees. This means that on the most optimistic assessment from the state government's point of view it has lost more than 25 percent of its system's coverage. On the least optimistic it has lost perhaps 50 percent of its coverage.

The transfer from state to federal coverage is continuing. Process is underway which it is expected will eventually see large numbers of employees in clerical, retailing, and perhaps teaching services covered by permanent federal awards or agreements. The major area of remaining doubt concerns the future of Victorian state public servants. At the present time there are legal obstacles preventing a move of state public servants to the federal jurisdiction. These are, however, not insurmountable. In the event that state public servants are able to make the shift this would remove a further (estimated) 40,000 employees from the state's industrial system. Such a result would render the state system entirely inconsequential.

Given the general opposition by unions to any involvement with the new state laws, and the newly developed opportunities for Victorian workers and their unions to take up the federal option, it comes as no surprise to note the collapse of the state's industrial relations institutions. It is well known that members of the ERC are not fully occupied by the demands of their office. A few simple figures will serve to highlight this point. In the three years prior to the commencement of the ERA, the Victorian Industrial Relations Commission dealt with more than 500 industrial disputes referred to it in each year (1990-607; 1991-634; 1992-562). These figures do not include unfair dismissals applications which numbered, in each of the years, several thousand. Under the ERA, disputes may be dealt with by consent, pursuant to s.92. Disputes dealt with under this provision numbered 15 in the first ten months of the ERC's operation, and in the period January-September 1994 the number of disputes dealt with by the ERC numbered just 21. ${ }^{11}$ There have been no applications for new awards under the ERA, though as noted earlier the ERC has conducted reviews into expired awards of the former Commission to implement the safety net adjustment recommended by the AIRC in the October 1993 Review of Wage Fixing Principles. ${ }^{12}$ In short, the volume of business has collapsed, not surprisingly, with the abolition of compulsory arbitration, and attempts by the ERC

11 The large number of these disputes have arisen from matters brought by the Police Association of Victoria under the Victorian Police Force Award 1992. At least a third of these concerned the single issue of allowances under the award for members of the police force moving residence.

12 As at 1 September 1994130 of the 237 awards existing prior to 1 March 1993 had been adjusted. 
to shore up its position through a form of compulsory arbitration in wage adjustment hearings is now about to be legislatively blocked (clause 12 of the amending bill). Whilst there is capacity for the ERC to hear disputes in joint sittings with the federal tribunal (s.115, ERA) there are no instances of such matters arising since the ERA commenced. One or two matters have been referred to the ERC by agreement in cases where federal jurisdiction has been contested.

The major field of activity of the ERC has continued to be in the area of unfair dismissals. Victorian industrial relations was already overwhelmingly marked by unfair dismissal applications from the mid-to-late 1980s (Benson, Griffin, and Soares, 1989; Johnstone, McKenzie, and Mitchell, 1993). As noted earlier, the ERA subjects applications for unfair dismissal to a greater array of conditions and procedural steps than previously was the case. It was expected that this would have a negative impact on the number of cases being brought before the ERC, and this has proven to be correct. These developments have to be seen in context, however. Overall there had been a slow decline in the monthly number of applications in the last year or so of the Industrial Relations Commission's operation. At times during 1991 these had peaked at over 500 applications per month but during 1992 had declined to about 300 per month.

There was, however, a further precipitous decline in applications towards the end of 1993 and in early 1994, so that applications were reduced to around 50-75 per month. It is unclear exactly what induced this decline. There have been suggestions that the flavour of the Victorian government's industrial relations regime came across publicly as uninviting to would-be applicants. The pronounced collapse in application numbers came in the period immediately prior to the ERA coming into effect. There are also suggestions, perhaps better founded, that preliminary advice being offered through the ERC's offices was unduly negative about the possibilities of success. Whatever the cause, the levelling out of applications has been more or less constant since March 1993 at an average of approximately 75 per month. ${ }^{13}$

The process for dealing with unfair dismissals involves a preliminary hearing, and then a referral to conciliation. Cases which remain unresolved at this point then proceed to an arbitrated outcome. A considerable amount of the CCAO's time is spent on the preliminary hearing process. Approximately 55 percent of cases dealt with by the ERC in the year ended 31 October 1993 completed the preliminary hearing phase (Employee Relations Commission, 1994). However, once the application is through the preliminary hearing phase the members of the ERC become involved in an attempt to conciliate the matter. According to the records of one Commissioner, since March 1993 he has been involved in 87 conciliation conferences over unfair dismissal, 72 ( 83 percent) of which have been resolved. If these figures are indicative of the general trend throughout the ERC, less than 20 percent of unfair dismissal applications which survive the preliminary hearing stage proceed to arbitration.

13 The available 1994 figures are as follows: 71-January; 102-February; 114-March; 50-April; 22May; 53-June; 48-July; 48-August. 
A major thrust of the new system was to produce a regime of employment agreements in place of the award system. As we have noted, the preferred outcome indicated by the legislation was for individual agreements to be struck between employer and employee which in the government's view would lead to a more flexible and innovative workplace (Gude, 1993). It is difficult to assess the success of this strategy, because the legislation requires only that the number of individual agreements entered into be notified by each employer on an annual basis. As at 13 October 1994, the CCAO had been notified of more than 353,000 individual agreements. Since none of these are available for scrutiny it is impossible to determine their content. All the evidence suggests, however, that only a small proportion of these individual agreements vary widely from the regulation of awards which preceded them. There has been widespread reported resistance to the signing of individual "flexible" contracts in both the private and public sectors of industry. It seems safe to assume that the vast majority of individual agreements have simply continued on the same terms as applied in the award roll-over process which took place on 1 March 1993 (Fox and Teicher, 1994).

Unlike individual agreements, employers are required to lodge collective contracts with the ERC's Administration Office. As at 13 October 1994, a total of 297 collective agreements had been lodged. Many of these regulate the employment of only a handful of employees. ${ }^{14}$ As at 3 October 1994, some 91 collective agreements indicating numbers of employees covered had been lodged in this calendar year. Of these, only 17 agreements covered more than 50 employees in the one enterprise. Only one agreement covered more than 100 employees.

Fox and Teicher have carried out some initial research on thirty employment agreements lodged prior to February 1994. An analysis of the provisions of these agreements revealed only a few instances of commitment to meaningful employee participation in enterprise management and very few instances of meaningful performance-based pay schemes, clauses dealing with functional and numerical flexibility, and other labour process issues. In short, both in terms of coverage and content, there is no indication to date of the widespread industrial reforms hoped for in the ERA.

\section{Conclusion}

In this necessarily brief sketch we have dealt with the introduction of the ERA, the critical aspects of its provisions, the response of the Australian labour movement and the consequent impact upon the Victorian industrial relations system.

There is no doubt that the ERA represents the most far-reaching instance of labour market deregulation so far adopted in Australia, and that it shares much in common with the earlier New Zealand reforms in the Employment Contracts Act 1991 (Mitchell, 1993(b)). For the reasons outlined, however, the reforms have failed to achieve their stated objectives. Most major Victorian employers have continued to employ workers under pre-existing award standards, or have become covered by federal regulation. There

14 Approximately 33 percent cover fewer than 10 employees. 
has been little effective use of so-called "flexibility" contracts, and the media has been quick to expose flagrant abuses. There remains, of course, an underbelly of dodgy contracts and practices, but these have always existed in the small business sector in particular. The ERA has, to some extent, made those practices legal, and perhaps extended their incidence, but has done little to engender the type of "creative" flexibility that the government must have been hoping for.

All of this pales into insignificance, however, when it is compared with the obvious impact upon the Victorian system. It has effectively been boycotted by federal intervention, and unless some of the Victorian government's legal challenges to federal paramountcy are successful, it will be left with no meaningful industrial jurisdiction. Perhaps the state government can claim success in that its confrontationist reforms have driven the federal government's agenda further than it might otherwise have been taken. Such an argument, however, smacks more of an ex post facto rationalisation, rather than a deliberate strategy.

It is seldom the case that a government's policy deserves little but condemnation. But the case of the Employee Relations Act is surely an exception. The government acted hastily in assuming that there would be a Liberal Party led government in federal office in March 1993. It was unduly confrontationist in pressing home its reforms with little opportunity for realistic political or public debate. The quality of its preparation and advice has been subject to constant and widespread criticism. The public utterances of some associated with the government's strategy have given rise to concerns (quite unfairly) over the independence of the ERC itself (Age, 1994). And in the end the government has shot itself in the foot. Even if it retains its jurisdiction over Victorian public servants, a matter yet to be decided, its system is hopelessly reduced in status and influence. This is a position that is likely to be maintained whilst there is a Labour government in federal office.

\section{References}

Age (1994), Industrial Tribunal No Lapdog, 2 July.

Brook, P. (1990), Freedom at Work: The Case for Reforming Labour Law in New Zealand, Oxford University Press, Auckland.

Benson, J., Griffin, G., and Soares, K. (1989), The Impact of Unfair Dismissal Legislation in the Victorian Jurisdiction, Australian Journal of Labour Law, 2: 141-156.

Creighton, B. (1993), Employment Agreements and Conditions of Employment under the Employee Relations Act 1992 (Vic), Australian Journal of Labour Law, 6: 140-158.

Employee Relations Commission (1994), First Annual Report by President of the Employee Relations Commission of Victoria, Year ended 31 October 1993.

Federal Coalition Parties (1992), Industrial Relations Policy, 20 October 1992. 
Fox, C. and Teicher, J. (1994), Victoria's Employee Relations Act: The Way of the Future? Unpublished paper presented to the 7th AIRAANZ Conference, Sydney, 10-12

February.

Gude, P. (1993), Changing the Landscape: Employee Relations Reform in Australia, The Eighth Foenander Lecture in Industrial Relations, University of Melbourne, 25 October 1993.

Johnstone, R., McKenzie, D. and Mitchell, R. (1993), The Industrial Relations Commission of Victoria 1982-92: A System Under Pressure, Australian Journal of Labour Law, 6: 97-120.

Mitchell, R. (1993a), Notes on the Employee Relations Act 1992 (Victoria), Working Paper No. 70, Department of Management and Industrial Relations, University of Melbourne.

Mitchell, R. (1993b), Economic Rationalism and Labour Law in Australia: The Employee Relations Act 1992 (Vic), Employment Law Bulletin, Butterworths, Wellington, 1: 5-9.

Naughton, R. (1993), The Institutions Established by the Employee Relations Act 1992, Australian Journal of Labour Law, 6: 121-139.

Pittard, M. (1993), Industrial Conflict and Constraints: Sanctions on Industrial Action in Victoria, Australian Journal of Labour Law, 6: 159-182.

Second Reading Speech (1992), Second Reading, Employee Relations Bill, 28 October 1992.

Watson, G., Guide to Victoria's Employee Relations Law, CCH Australia, Sydney.

\section{List of Cases}

Review of Wage Fixing Principles: October 1993 (1993) 51 IR 54.

SPSF decision: (Reference pursuant to section 113A of the Employee Relations Act 1992 (Vic) to review the operation of those provisions referred to in clause 22(1) of Schedule 6 of the Public Sector Management Act 1992 (Vic.), ERC in Full Session, 3 June 1994, Dec E94/0157). 